\title{
WestVirginiaUniversity
}

THE RESEARCH REPOSITORY @ WVU

Graduate Theses, Dissertations, and Problem Reports

1939

\section{The Correspondence Between Thomas Jefferson and Philip \\ Mazzel 1779-1815}

Mary Teresa Lippucci

West Virginia University

Follow this and additional works at: https://researchrepository.wvu.edu/etd

\section{Recommended Citation}

Lippucci, Mary Teresa, "The Correspondence Between Thomas Jefferson and Philip Mazzel 1779-1815" (1939). Graduate Theses, Dissertations, and Problem Reports. 10150.

https://researchrepository.wvu.edu/etd/10150

This Thesis is protected by copyright and/or related rights. It has been brought to you by the The Research Repository @ WVU with permission from the rights-holder(s). You are free to use this Thesis in any way that is permitted by the copyright and related rights legislation that applies to your use. For other uses you must obtain permission from the rights-holder(s) directly, unless additional rights are indicated by a Creative Commons license in the record and/ or on the work itself. This Thesis has been accepted for inclusion in WVU Graduate Theses, Dissertations, and Problem Reports collection by an authorized administrator of The Research Repository @ WVU. For more information, please contact researchrepository@mail.wvu.edu. 
The correapondence Between thomas Jefferson and Fh12p Hazel.

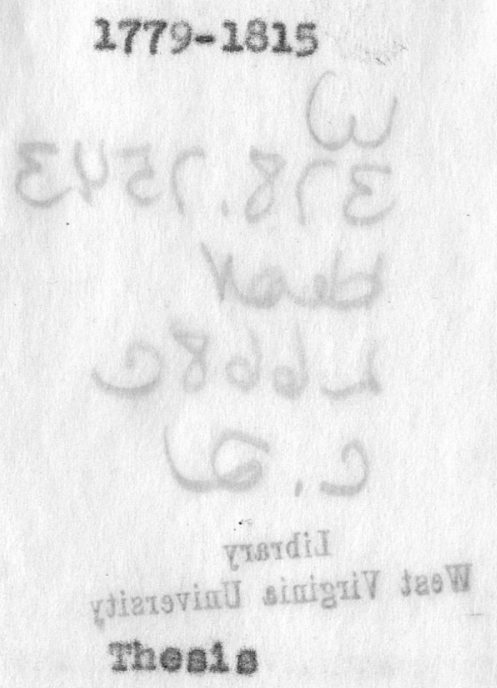

Subaltted In Fartial Fulfildment of the Requirements for the Degree of Master of Arte in the Faculty Araduate sohool of west Virelnia Univeraity

by

Hary Therosa Luppuoed, A. B. Morgantom Weat V1rginia 1939 


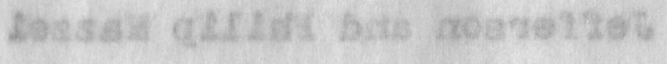

actes-erts

$$
\omega_{378.7543}
$$

bear

$2668 \mathrm{C}$

c.

Library
West Virginia University

abae the

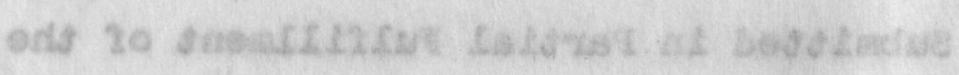

20 esmoki edis rol astrodiersupon

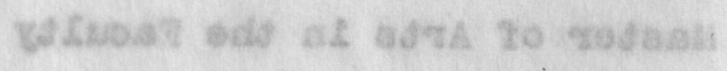

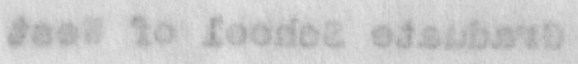


The Corregpondence Between Thomas Jefferson and ThIIIp Hazzel

$$
1779-1815
$$

$$
5 / 8988
$$


Chapter I

1. Lafe of PhIMp Mazze1............ I

2. KhILp Lazzel's Interest in America. 5

3. Thomas Jefrerson's Interest in PhL11p Mazzel.

Chapter II

1. Ph114p Mazze1' a Hsalon to Europe... 13

2. DLapatahes to Thomas Jefferson from

Novenber 27, 1779, to March 8,

$1782 \ldots \ldots \ldots \ldots \ldots \ldots \ldots \ldots \ldots \ldots, 22$

Chapter III

1. Jefforson's Letters to Hazzed...... 38

2. The "Fanous Mazzel Letter"

Apr11 24, $1796 \ldots \ldots \ldots \ldots \ldots \ldots \ldots .44$

Chapter IV

1. Mazzed' Letters to Jeffermon....... 49

2. Conclusion..................... 57 


\section{Drerace}

The present aanusertpt is a study of the correspondence between Thomas Jerrerson and Fhl11p Hazze1, an Itallan emlgrant.

Belng of Itallan parentage, I was interosted In sinding out what itallens heve done to ald in the development and progress of thelr adopted country. Therefore, ThLL1 Hazzel wes brought to ay attention by Dr. O. H. Ambler, Professor of History, at Hest Virginis Univers1ty, as an outetanding Itallan end rant who loved and served the United States. To carry on agrlculturel expenlment work, he casie to Amerlea Just before the Amerlean Revolution, but was later sent to surope on a epeclal alselon for the state of VIrginia, to borrow money. The story of his progress and fallure can be told only by the correspondence between rhillp Ma $\mathrm{a}_{2} 2 \mathrm{~L}$ and Thomas Jeffergon, hs dearest rrlend. That is what I have atterpted to do In writing this theste.

I welcome thls opportund ty to express. ay appreclation to Dr. O. H. Ambler, who has dreoted and advised tho work and ande many valuable 
sugsestions and corrections. I also express my thanks to Dr. T. E. Enn1s, for helpful guldance, and to Amerlgo Cappellarl, for havine tranalated Italian letters Into English.

$$
\text { H. T. L. }
$$




\section{GAAPTER I}

\section{Life of millp Hazzel}

Th121p Mazzel was bom at Poge10-aCalano, a sall tom near Florence, Juseany, on December 25, 1730. Litule is known of his youth except that he stualed medine at the hospltel of santa Maria Muova in VIorenee, and was alsmlsed for aome minor offence. ${ }^{2}$ After the desth of hls father, Mazzel was forced to eam his own 11ving. He went to 11ve with relathves In 14 se where he began to prectice medielne. While living $1 \mathrm{n}$ PLa he becase friendiy with Dr. Sallnas and Urs. Sellnas, who urged Mazzel to return with then to smyrna, which was thelr home. He accepted and lert with them in August, 1752. Fop about three years liazed IIved $w 1$ th Dr. Salinas and practiced medi olne, thus enabling the young coetor to become acqualnted with aany influential men.

But he did not remain long in Smyma. About 2756 he went to London, where he 11 ved nearly elghteen years. In London he becane a

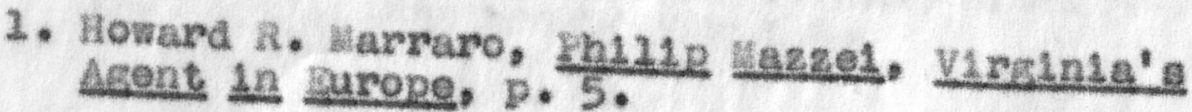


teacher of Itallan, not on $2 y$ for the money whloh he could earn, but also for the advantageous connections and acqualntances whloh he belleved ho could make in this way. He later organlzed the firm of uartin and Company ${ }^{2}$, whi eh imported wines, ollve olls, ete., into Burope. When hls exployee died, Mazzel proml sed to look after his wlfe and daughter. He later married Hre. Hartin, not because he Loved her, but he wlshed to make home conditions good for the daughter, whom he dsd 10ve. He did not get along weil with hls wife. In 1765 he wade a brlef vialt to Italy, but was banlehed from his native country by the Inquisition, on the charge of 1mporting into Iuseany certaln booke banned by the Church. However, he was later relnstated.

Maszel returned in $\mathbf{1 7 6 7}$ to London, where be continued his eonnections with Martin and Company. It was about this the that he comenced to becone interested in America. HL flrst eontaet with outstanding Amerlesns In London was

2. The f1rm of Martin and Company was really owned by Mazze1, but he wae afrald it would hurt his prestlge with the influentlal aen he knew if his nasae were given to the Pl.rum; so he oalled it Martin and Company after the Mr. Martin, who woriced for hia. 
brought about by the arand Duke of Tuseany, who asked hia to purohase two Franki. in stoves. 3 Thlo made it posesible for him to become acquainted w1th Dr. Benjanin Frankiln, RLchard Neave, w111 an coosley, and Thomas Adams. ${ }^{4}$ It wasn't Iong after this meeting that sone of these men succeeded in getting Hazzel to fom a company for the purpose of pronoting in Virginia the cult1vation of slik worms, ol1ves and grapes, and also buliatng up a wine industry. But before he lert for Amerlea, he returned to Italy to obtain men and waterlal. He lert Italy wlth $\mathrm{hls}$ cargo on septeaber 2, 2772 , and arrived in virginia nearly throe monthe later.

In Virginia, he met deorge lashington, deorge wythe, Thomas Jefferson, and other prominent Amerlcane, who alded lazzel in his now enterpmse by forming a company to assist him flnanelaliy. Thomas Jerferson becane one of 1 ts menbers .

However, Hazzel's place in Amerl can

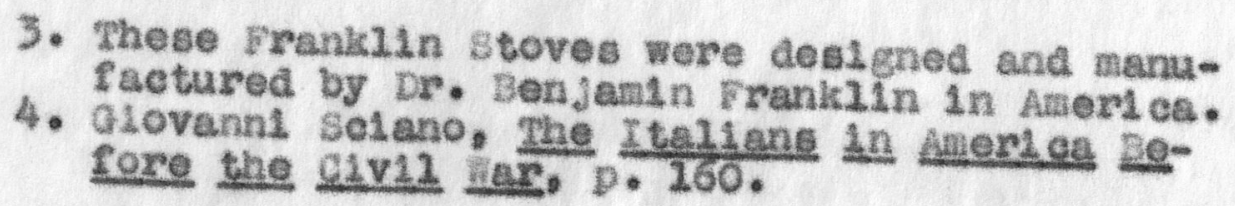


hletory is not one of a ereat producer of wines, but ohler2y that of an envoy to Burope to obtain ald for Virginia in the form of roney and supplies aurlng the Colonies" strugele for Independence. Nazzel went to Durope as V1rginia's agent in 2779, and arter several years of unsuceosarul work he roturned to Ameri ea about 2733. He apent sone the fintahing ofriclal business with the state of Virginia and vialting old frlends. About June 16,2785 , he auled for arope. It was generally belleved that he would return to his adopted country artor a vist in Darope, but he ala not.

Mazed later beoane employed by the king of Foland as agent to Parls. Unfortunate1y, there are no avallable letters from whloh aan be gathered any facts conoerning $h$ s 21 fe between the spring of 1790 and that of 1796 , when ho was in the omployment of the king of poland who wab later forced to glve up his throne and rlee to Rusis. Hazzel returned to 1 sa, where he died on Warch 19. 2816.5

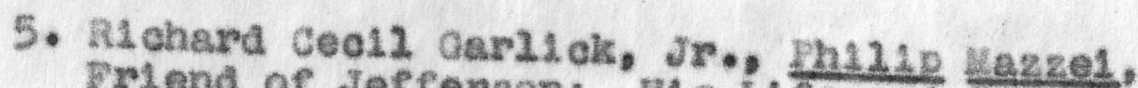
Driend of Jefrerson: H1e Lire and Letters. 
2. InLLip Hazze1's Interest in Ameries

At flrst Fh111p liszel was not very enthuslastio about coralng to Amerlea. He was afrald the governaent would be a bad eopy of that in England, and therefore freedon in Amerlea would be even less. However, whch men as Dr. Benjanin Jrankiln and John cuinoy AdamB convinced $\mathrm{hln}$ that there was wuch freedon and good government in Amertca. He writes in his "MenOlrs":
... [thoy] convinced me that there was no arl stoeracy, that the people were not blinded by the splendor of a throne, that every head of a fandiy had the right to vote and to be elec- ted to orfloe, that they had their own munlel pal laws and that only those Bngli ah laws had been adopted, which were most convenient to them. ${ }^{2}$

Mazzel finaliy decided to come to Amerlea as the plans had been arranged for the agricultural experiment. After his arrival he spent a anall portion of $\mathrm{hl}$ s time with $\mathrm{hls}$ agrlcul tural work.

Thls letter written January 25, 1793.

1. GLvann Sohlano, the Italuans in Aarorlea Defore the c1v12 var. p. 176 . 
to Albert Gallatin by Thomas Jefferson $\mathbf{w 1 1}$ explain fully the orlesinal reason for lazzel's comlng to Aserlea and the alteration of his plan:

sir, - Mr. Segaurx ealled on me this moming to aak a statesent of the experiment which was made in Virginta by a Mazsel, for the ralalng vines and making wines, and desired $I$ would address it to jou. Mr. Mazzel was an Ital1 $\mathrm{n}$, and brought over with him about a dozen laborers of his own country, bound to serve his four or five years. We made up a subseription for him of 2,000 sterling, and he began his experiment on a plece of land adjolning to mine. H1s intention was, before the time of his people should explre, to $1 \mathrm{~m}-$ port more froti Italy. He planted a conolderable vineyard, and attended to it with great alilgende for three years. The war then eame on, the time of his people soon explred, eome of them en11sted, others chose to settle on other lands and labor for themselves; some were takon eway by the gentlemen of the country for gardeners, so that there did not remain a aingle one with him, and tho interruption of navigation prevented his importing others. In this state of thinge he was himelf exployed by the state of Virginia to go to Europe as thelr agent to do some particular business. He rented his place to coneral Riedesel, whose horses in one week destroyed the whole labor of three or four years; and thus ended an experiment. .... This $1 \mathrm{~s}$ the suin of the experiment as exactiy as I am able to state $1 \mathrm{t}$ from memory, after

2. Albert wliery Bergh, The writtinge of Thomag Lefferson, vol. 9, $\mathrm{pp} \cdot 14-15$. 
From the Leglalature of Virginia Thomas Adas had arranged a grant of five thousand acres of land on which Mazzel was to conduct hls agrl cultural experlmenta. However, llazzel refueed the grant beesure it was alvided into anal1 pleces apart from one another.

Hazzel then started out rather almlossly to flnd wore sulteble land for his experimentation. On bis way he stopped at "wont1 ce110", the hoeve of Thoras Jefrerson. Wh110 talking with Jefreraon, Hazzel found that he was twich interested in agriculture, and flnally Jerferson persuaded Mazzel to buy a small tract of land adjolning his own. Ho aleo gave Hazzel about two thousand acres of hla own 1and. Maszol at once sent for $\mathrm{hls}$ men and started to work. Jefferson helped him make his plans and looked after the work during llazze1's absence. They became good frilends and alao became intensely interested in the polltical 11 fe of the colonies, espeelaliy in that of virglnia. Mazzel and hls famlly 11 ved with Jefferson unt1l the former's home was IInished, and upon Its completion Mazzel called $1 \mathrm{t}$ "cello".

3. Mazzel called hle place "Collo", elther in contradiction to "Monticel2o", or because 1 t was bullt on a sall hill, or maybe after cello, 
3. Thomas Jefreraon's Interest in Fhlilp Hazzel

Thomas Jefferson becare intensely interested in PhILlp Hazzel for several reasons. They had in common many ldoas and interests, buch as agricultural, politieal and religlous vlowpolnts. Hazzel becane on of Jefrepson's closest friends and devoted wuch of his time to Jefferson. Their chlef Interest was American freedom from lagland. They not only diecussed thls matter between thenselves, but also wil th other outetanding Amerl cans. They wrote many articles whlch were published and alstributed among their friende in order to win them over to their slae.

Thilp Haszel sugsested to Jof ferson that if indepondence from England vere destred, "... 1t was Inclapensable that they abandon any admiration they might have for British politlas Institutions [uoh as, the Britiah constitution]" . Jefferson was surprised at this statenent at first

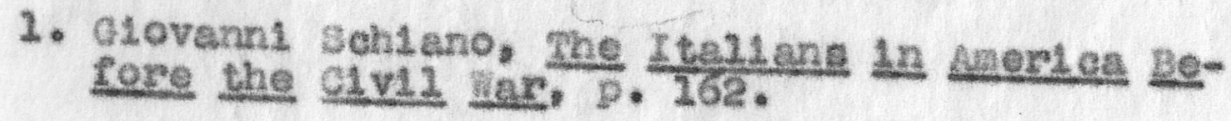


but later agreed with Mazzel that it was a good polley*

It was then planned thet Lazzel write periodically a number of papers on this subjeot. They were to be written in Itallan and tranglated by Jefferson Into Bngli ah and were to appear in the Virginle Gazette for the purpose of bringling the laea before the Anert can public. They wore published as a series of articles from 2774 to 1775.

It is not generally known, however. that he exerted great influence on the Fathers of the ropubile, that he worked Incesaantly to change the attltude of the Anerlean people and thelr leaders towards Brlts oh politi eal institutions and that he actual1y preceded Thoman Palne and Thomas Jerferson in thels denunclation of the British covernsent and in the atssemination of the prinelples of eguality and true denocratic government. 2

It hae been polnted out by historlans that some of the very words of the "Declaration of Independence" are found in an artiole written durlng thls perlod of $1774-1775$ by Mazzel in Itallan and translated by Jefferson Into kngll ah and publishod in a Virginla newapaper. A para-

2. Ibla, pp. 160-161. 
graph taken from one of Mazzel's artieles, using works which are found in the "Declaration of Independence" showe the similarity:

Al1 men are by noture ereated free and independent. Such equali ty is necossary lin order to ereate a froe government. It 18 necessary that all men bo -qual to oach othor in natural law. Clase distinetion has always been and will alweys be an effective obstacle and the reason for it is very clear. When in a nation you have several alasses of men a.1 must have their share in the government of the country; gtherwlse one class would doninste the other. But esch share cannot be made porfectiy equal; and even If 1 were possible they could not be aalntained in perfect balanee; and as soon as one exceeds the others the whole sust cruable. That is why all anclent ropubllos did not last long. ... I repeat $1 \mathrm{t}$, a true Republi can government esnnot exist unzess all men from the rieheat to the poorest aro perfectly equal in thels natural rights. ... This government of England, fros 1 ts earliest times, unt11 the death of Gueen El1zaboth was el ther a despotie monarehy or an intol erable aristooracy or mixture of both.?

Mazzel not only alded the American government with his writings, but while in burope on his mission aleo gathered valuable information which he sent in the form of aispatches to Jefferson (alscussed in Chapter III). ${ }^{4}$ the secured millary and rinanclal ald during the

3. Ibla, p. 265.

4. IbId. D. 171-172. 
American Revolution. He also Arew up a plan for the eapture of the Brit1 gh aray in New York. The same plan, wlth a few changes, was later used offectively at Yorktown in that it brought about the surrender of Cornwel11s.

In $2776 \mathrm{Man}_{2}$ el helped Jerferson in bringing about many reforms in virginia, incluaIng a revision of the legal code of that state. Together they also discussed religlon and slavery, but on the question of slavery they asffered. Jefferson dealred to free the slaves outrlght, but Hazzel argued w1th hin that thls was a bad polioy. He thought that the slaves should be freed gradualiy because they outnumbered the whltes two to one, and thls superiorlty of numbers might give the white an reason to fear the power of the Hegro. The Itallan convinced Jefferson and others of the advisability of hls plan, and, as a consequence, education of the slaves was begun.

Through Jeffergon ho eame into contect with some of the leaders of Amerlea. Hazzel loved hls adopted country so much that when he was asiced to represent the state of V1rginia in Burope, he was only too glad to sccept. Fros these interests 
whl oh he manifested we can see that taszel contributed a great coal in alding the Americans to galn thelr freedow. It $1 \mathrm{~s}$ belleved that only flnanelal condtions caused him to return to Burope and stay there unt12 his death in 1816. 


\section{CHAPTER II}

1. Fh1ML Hazzel's Miseton to Burope

Thomas Jefferson and othor leading

Virginia stateanen in 1778 had boon saking plans to send Hazzel to Europe for the purpose of encouraging more immigration to Aserlos. This plan was soon absandoned, for at thl a time a more urgent need for virginia was that of money and army supplles. It was declaed by Thomas jefferson, Patriok Henry and others, that Hazzel would be of far more use if he were sent to Burope for the purpose of borrowing money frow hls frlend, the arand Duke of Tusenny, for the state of V1rglnia. ${ }^{2}$

Thlo Italian immigrant to the United States had admirable qualifications for this 1mportant miselon, beeause he was of Tusean blrth, a merchant of great expertence, a Juage of men and their natures, and a writer. He, thererore, was their logleal cholce, and recelved his appolntment from the Governor of Virginia, Petrick Henry, and the Virginta couxes I In January, 1779.

1. James Iarton, "Jef ferson covernoz of Virginla", Atlantle Monthy. Vol. 30, D. 175 (August, 1872́). 
A sumiary of his instructions was that: "He was authorseed to obtaln a loan of gold and sliver, not exceeding 900,000 and to purchase goods in Italy for the use of the state troops." Mazzel deslred to have only hls expenses pala; ho did not aak for a compenoatlon. On AprL1 21, 2779, he olgred tine oath of alleglance, and on June 29 of the sane year he salled on $\mathrm{hlo}$ mlseion to serve his adopted country and atete. Fron the very beglnning of his miselon Mazzel ran into trouble, which followed blm continueliy. He had so planned and arranged his orrlelal comalselon and Inotruetions that in caso of capture at sea they could be easlly destroyed. HL plan was to put hla ofrlelal papers into a bag w1th a lead welght and throw them overboard. After several daye at sea" he found it necessary to carry out hls plan whon hls shlp was captured by the Brithah. Mazzel hiagelf wrote of his 1 tention:

1 had a dary in which I wrote all the things 1 hed to attend to in the verbrovlated in such not possible for another to underetand

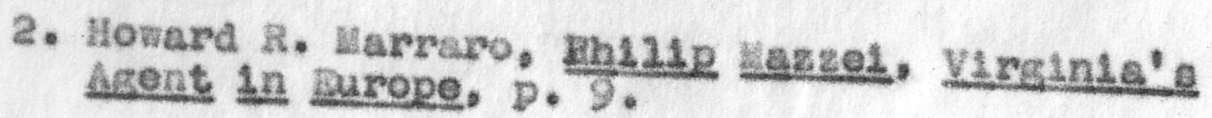




\begin{abstract}
thel meaning. I used the sase sohene for my oxedentials and for my instructions, and I put everything in a gal1 sack welghted with lead, to be cure that 1. would not fall into the hands of the eneny.
\end{abstract}

When eaptured "I descended to ny stateroom, and as soon at the privateer ease alongslde, I threw overboard, whout belng observed by anyone the 11ttle sack with a11 my papers." Lazzel was taken to New Xork, where he was a prisoner of war for three monthe. A1though he and his family were retalned, they were allowed to IIve on Long Ialand In a private home. This long delay proved gulte expenstve to llazzel, both finanolally and so fax as hls alsalon was concemed.

When he wae roady to undertake the work for whloh he had been sent. However, ho found that his hande were tled beetuse he was ladklng the necessary credentlals, having destroyed his offlelal conmission and instruetiong before his arrival. He wrote at once for duplleates, but wh11e walting

3. E. C. Brancht, Tr." "Hemolrs of Mhl1Lp Hazed", 11111am and Hary college gurterly, Second Sories, VoI. 9. W0.4, D. 254 (Cotober, 1929). 4. Ible, p. 254. 
for them he was busy collecting userul infornsthon from several suropean countries and sending dLapatches to whomas Jefferson, then Governor of Virginia. These dispatches are very Important documents, but they are not to be found in any. ealtion of Jefforson's writings, or In Mazze1's, nor anywhere else.5

Mazzel carerully numbered all these seports he sent to Jefferaon. He also kept a record whl oh destgneted who earried hla letters, and how and when they arrived at thel $r$ destinetion. He wade four coples of each letter he wrote, and each was sent by a different route. Hazzel could deteralne from known ahip arrlvals in Aaerdoa jugt which one of his letters had been recolved.

The following 11 st of his al spatehes which Jefferson recelved show how eompletely they covered Mazze1's miseion in Durope.

$\begin{array}{ll}\text { No. } & \text { Erom } \\ \frac{1}{2} & \text { Nantes } \\ 3 & \text { Nantes } \\ 4 & \text { Nantes } \\ \text { Nantes }\end{array}$

Dated November 27,1779 Decomber 5, 2779 Decomber 12, 1779 Decesber 18; 1779 and January 9, 1780

5. Howard R. Harraro, Phille Mazzel, V1rginla's Aseit in purope, p. 10 . 


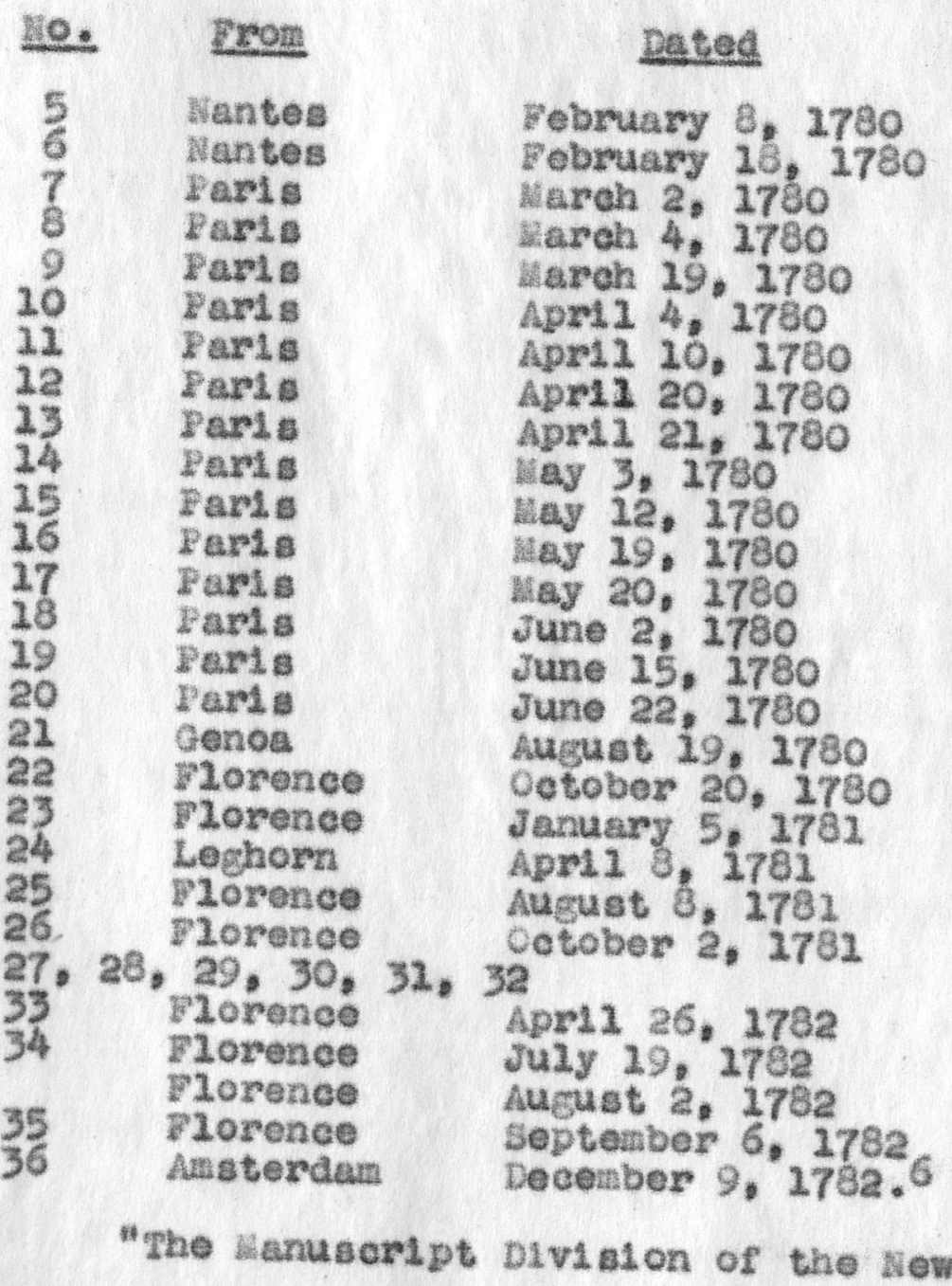

Yorle Pub11e Library also presorves monoranas in the handwritling of llazzel showing how he forwarded $\mathrm{hls}$ al spatches to jerfereon. These notes Indl cate who carrled his letters, [as woll ad] how and when. Bince each letter was numbered and four coples were eent by different routes, Mazzel could deteralne from known shp arrivals

6. Ibld, $p p \cdot 10-11$. 
In Amertea whloh of hls letters had been reeelvod. The wemorande follow:

let letter per the Ceelle, Gapn Fridin, via Charles rown

the Isabelia, Capn Trippe, via Daltinore

the Kenelrigton, $\operatorname{Cap}^{n}$ smlth, v1 a FhLladelphla

the Independence, $\operatorname{Cap}^{n} \mathrm{kIrk}, \mathrm{via}$

and lette Thiladelphia

the kenslngton

the Belsey, Capn Boardaen, for Virginda (taken ap. 12)

the Saliy, Capn Cogethali, for Virginla

the rom Johnson, $\operatorname{Cap}^{n}$ Hartin,

3rd letter

the Tom Johnson v1a Annapol1

the Betsey

the sal.1y

the A111ance, cont ${ }^{2}$ rregate, con-

4 th 2etter modore Jones

the Tom Johnson

the Betsey

the Bally

5th 2etter

the Al11 ance

the Betsey

the Kensington

the saliy

6 th 2otter

the Alliance

the Betsey

the Kensington

the Baliy

7 th letter

the A111 ance

favis of llarquis de la Fayette

the sally, eap cogsahall

the Kensington

8 th letter

the All1 ance

the Kensiagton

the Baily

the Luzerne, Capt Bell

9 th letter

the Al11ance

per the Alliance

the comitte, Gapn Brisson, via Fhl ladelphia

the Dove, Cap ${ }^{\text {n }}$ il eKeray via Baitimore

the Luzerne, Cap ${ }^{n}$ Bell 


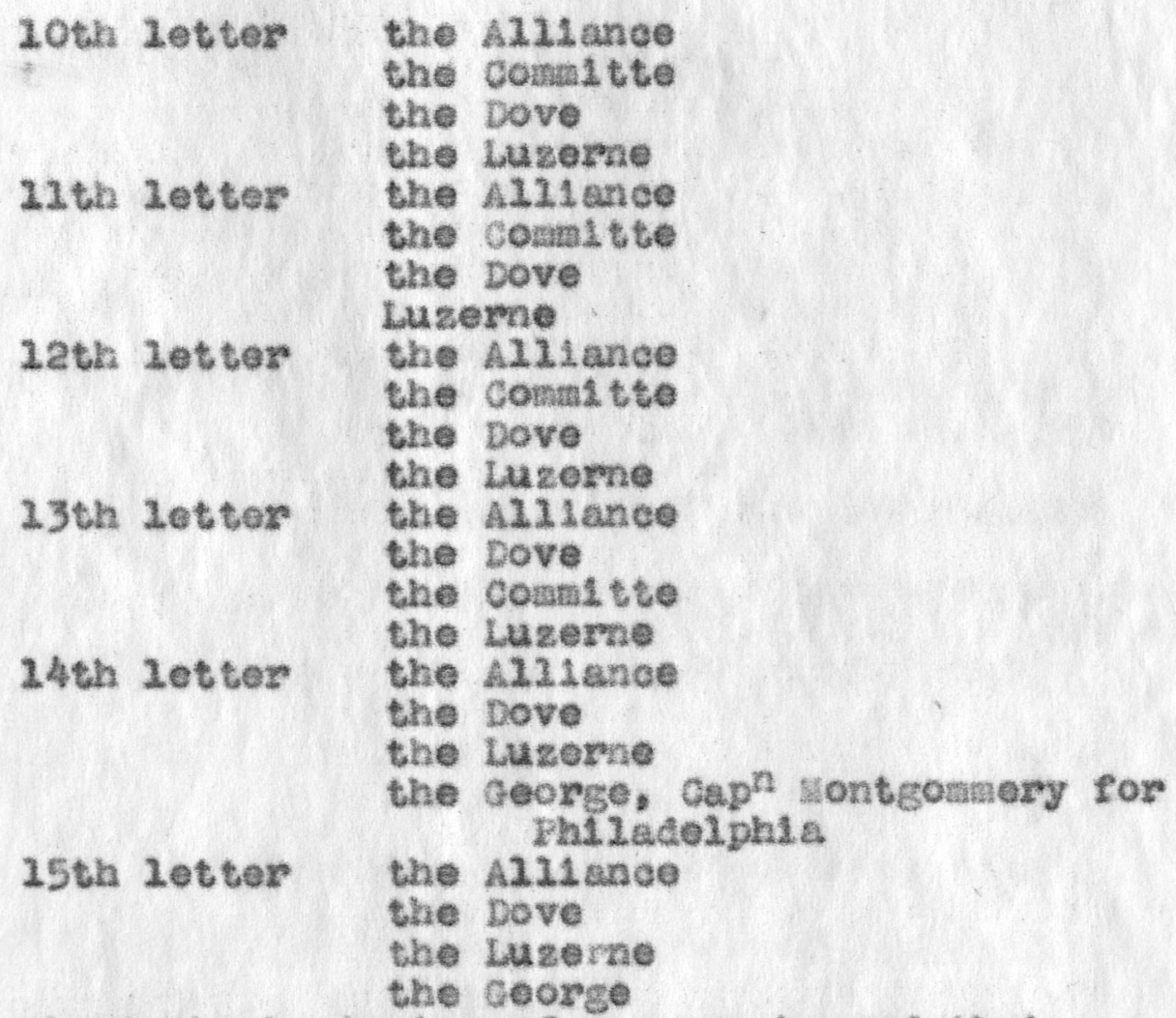

About the beginning of may, we heared that the lasbellas \& the Independonce were arrived, but I have no certalnty of 1 t.

$$
\text { * * * }
$$

16th letter

17 th letter

18 th letter p. the Luzeme

p the Dove, Cap $^{\mathrm{n}}$ MeKerdy for Baltimore

p the Duke of Lelnster, Cap $^{n}$ stour for Ihlladelphla

p the Ariol frogate Cap $^{n}$ Jones

$p$ the Luzerne

p the Dove

p the Duke of Lelnater

$p$ the Artol rrogate

D the Kensington, Cap" Smith for Thlladelphia

p the Ariel fregate

p the Duke of Lelneter

p the Luke, Cap ${ }^{n}$ Clarke for Philadelphis 
29th 2otter

p the Kensington

$p$ the Arlel rrogate

p the Duke of Lelnster

20th Letter

D the Luke

$D$ the Keneington

p the Arlel fregate

p the Duke of Lelnster

p the Luke

21st letter sent to W. John ACaris at Farle

p the Hercules, Caph Keary for Baltimore

p the Mars fregate dap Janson for Bogton

p caph Roblson, passenger on board

2and letter the thip inarequis La Fayette Sont to $\mathrm{kr}$. Adeasen at Parls $p$ the Hercules

p the tars

bapn Roblaon, ac above." 7

Mazze1's wission was frulthess. He

blamed his fallure largely to the neglect and indifference of the state of Virginia. whlle reading over llazzel's Alspatches and the story of his alsaton, one sees that the virginia ceneral Aasembly made no mistake in sending liazzel and if it had eupported $\mathrm{him}$ i $11 \mathrm{thle}$ more than 1t Ald, he mleht have been able to accompli sh a great deal moro.

Hazzel was rewurded for h1s servi ces to the state of Virglnia. "The covernor called a meeting of the coundil on June 10, 1784, and they declded to glve me six hundred louls a yoar fros

7. Ibla, pp. 12-12. 
January 8, 2779, to Apr11 8, 1884, w1 th one copy of the following resolution slaned by secretary Blalr, 'That in all that tias $4 r$. Hazzel had demonstrated activity, aseleulty, and zesi; and the bad outeome of that affalr was not lmputable to hin, but to certaln speelal elrounstances; and that his behavior deserved the approbation of the Counc12." For P1ve years and three months they gave me three thousand one hunared and rifty lous : " 8

8. I. C. Branchs, Tr.. "Meno1rs of Th111p Mazze1", 21111an and Hary co110se euarterly, Second

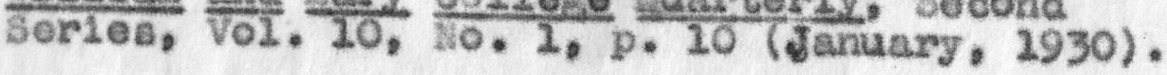




\section{Di spatches}

November 27,1779 , to Warch 8,1782

Lazel wrote his flrst offielal letter to Thomes Jerferson dated Nantes, Novenber 27, 2779. He Infomed Jefferson of the recovery of his 11 berrty, of the deplorable state of hls $\mathrm{fl}$ nances, and of $\mathrm{hl}$ es al sappolntuent for not having found in France the dupllottes of his comisston and Instruetions.

I an et a $10 \mathrm{se}$ what to do for want of my papers. I mentioned more than once to the 1ate Governor, Mr. Page, and col. Maddson [ale] the proprlety of sending several cuplicates of my conmissione and instruetions by the pirst opportunt tles. I even did romeaber lt to col. Madal aon in one, of 2 , of my letters dated on board the Johnston 1 Sal th in Rappahannack, or York RIver.

In the sase letter he mentlonea that he had recelved some eash from $1 r$. D'Acosta ${ }^{2}$ on aceount of the letter of credst, and that the whole sum of three hundred louls $\mathrm{A}^{\prime}$ ors would not be pald untli. that house had recelved some remlttanees fros Anerloa. He stated further

1. Howard R. Harraro, Bhlile Hazzel, Vlrginia's Ageht to Europe, p. 25.

2. D'Acosta was a member of a banking 11 m In Nantes, whlch bore his name, and from which Hazzel was Instructed to borrow money. 
that in France, American independence was looked. upon as certain. He also gave Jeffereon gonemal Infornation on the conditions in Furope at that partloular time.

In the second 2.etter, atted Docember 5 , 1779, he told Jerferson that we should not expeet any benef1ts because the Englith were occupled with the Irish commotions. However, he ald not glve his ressons in this lettor, but in a Later one. 3

In a letter of Decenber 12, 2779 , he pointed out that nine days bofore $1 \mathrm{t}$ had been agreed In the KIng's CouncLI at Versallies to Iend Congress such mil1tary arne and other things that they needed, to the anount of stxteen m12110ns of 11vros. He sald that he recelved thls information from a new acqualntance, an elderly $\operatorname{man}$ in whom he had much fasth and for whon he had a ereat deal of respect. He never revealed the Identity of the man, but often spoke of him in his letters. He told Jerferson the French version of count D'sstaing's

3. Benson $J$. Lossing. The Anerlean Hzetorienl Regord, Vol. $1,1872, \mathrm{p} \cdot 73$. 
dereat and hoped it was not true, lest France witharaw her support. 4

The accounts are varloun and confused; but they all seen to signify, that the count 1 s furious againet the Amerlcans; that he was not jolned by anythlng like the number of our troops he had boen promised; and that at the fire the Aserleans ran, and left him in the luroh: ete. D'Eatelng [ele] 18 reokoned a llero, and is now the darilng of rrance.5

In a letter started Decenber 18, 2779,

and Itnl bhed January 9, 2780, Mazzel related that the count had at last arrived in parls and the true story was known from the accounts D'Estalns gave to the prench papers. The followlng story appeared in the zrench garette:

Count D'Eateing finding many of his voseels much damaged by a strong gale, resolved to go no further north, and to undertalie the alege of Savannah w1 th the troope he had on board, to whom were Jolned 2000 men of the Unlted States commanded by cen. Lincoln. The comblned amy consisted of 5524 men. ... The 24th of sept, the sinemy made a sally, and was ropulsed with 200 s. Being imposalble to continue the slege for reasons a $e .$, the 9 th of october the retrenchionte were attackod. The

4. Estalng, Charles Hector Theoday, conte $a^{*}$ was the French admiral In command of the pleet sent to ald the united states agalnst Bm taln. 5. Howard R. Harraro, Wh111e Hazzel, Viretnig's
Agent in Burope, D. 18. 
Eneay Informed of the plan of attack by fugltiven had prepared the defense accordingly. The french [sle] and Anerdcans ettacked w1 th the greatest vigour, and returned 3 tines to the charge, but the suporigrity of number obliged then to desist.6

In the same letter he dealt again wh th

his flnanelal troubles and begged Jefrerson for

ald. In adaltion he enclosed valuable informa-

tLon about Russta and Foland:

... the very great probabl21ty, that Rusela $w 111$ preserve a perfect neutral1ty for powerful reasons, whl oh haraly aent $t$ of any doubt. I chall glve you another, which is a fact. The Irlsh after having made publl eic rojol clngs, in conseguenee of the 11 berty of trade already obtalned, now inelst on 11 berty of dovernment independent of the britlsh [alc] Parliament.?

Wazzel Inforwed Jefferson in a letter dated rebruary 8,1780 , that at 2ast he was forced to ask financlal ald from $\mathrm{hle}$ friends In Italy. He also wrote about the navles of the various countrles of Burope, the number of war shlps, thelr leaders, how well equlpped they were, etc. He told of the number whl ch would be sent to ald the Anerican colonles in

6. Ibla, $p p, 22-22$.

7. I510, D. 25. 
thetr struggle for Independenee.

On Eebruary 18, 1780, the envoy explasned the trouble he was having w1 th ur. Penet, who let him have fifty-three $10 u 1 s$ and elghteen IIvres in advance on his letter of eredit for throe hundred loule $\mathrm{d}^{t}$ ors. Ir. Penet refused to glve $^{\mathrm{h}} \mathrm{km}$ the fu21 amount unt11 he heard fros Amerlea. Hazzel now ceslred to return what he had borrowed and redeen hls letter of eredit. After wuch trouble he finally succeeded in fulfluling this obligation.

A Letter dated llaroh 2,1780 , from Parls was recelved by Jeffereon from Lazzel. He wrote of his meetlng with DF. Benjanin FrankIn and tho Marquis CaracoL0209, who were In position to introluce hlis to very influential men. He also sela that Harquis de la Fayette, who was returning fros hls native country, France, to Amerles where he had already spent two and one half years, would be of great holp to the Amertean cause. Agaln he mentloned his flnanelal

8. Wm. P. Palmer, calondar of Varclnia state Pepers, Vol. 2, 1875, Dp. $335-337$.

9. Caracolo10, Marquis Dement co, was Ambassador of the King of liaples to Faris. 
troubles, asklng for ald, and concluded by reminaing Jefferson to send him the auplicstes of his comalsston and instruetions.

In a letter on warch 4,1780 , he stated

that Irom Rappahannoek, or Xork Raver, he had written Col. Madison:

... that the season beling so far advanced I had a mand not to walt unt11 I got to Italy to proposo the exchange of goods on tho terms expressed in ay Inetruetions, and that least I shoula be taken, and of course be obliged to throw my papers over-board. I had interlined in sone of my privete old papers the elfer and substance of the busineas intrusted to me in order that I might prepare things as $\mathrm{far}$ as posalble by the time I ahould repglve the auplicates of my commisalons. 18

He told Jefferson that he had done Just as he had written Col. Madson; inclosed In 1t a demonstration of the impracticability of purchasing the goods in France on the terme preseribed to hin; signifled his hope for success in Italy by a proposod plan through which he hoped to encourage the people to become adventurers in Anerlean trade, pointing out the various advantages we would derive from 1t. He

10. 펼, D. 339. 
added further that his plan had been glven approval by Dr. Bonjamin Frankiln, who al wo proal sed him asel atance.

On Apr11 4, 1780, from Par1s, Hazze1 walled Jefforson a copy of "Ir. Burice's speech on presonting his Plan for the better securdty of the Indepondence of Farlianent and the Beonomleal Reformation of the CIv11 and other Estab11 ahmente." 11

Mazzel wrote in a letter started April 10, 1780 , and flni ghed on Apri1 19, 1780, fron Pards that England bollevod that the Russian Pleets and armies were to be constantly at her Alsposal. But liazze1 seld that the Enpress of Russia had sent out a mansfosto, in which sho notifled the belligerent powers of her flrm determination not only to keep tho atriatest neutrallty, but also to protect her trade. the Inslsted that her trading vessels should not be disturbed by any means. The kapress had sent thls mantfesto also to Denmark, Sweden, Holland, and Fortugal with an Invitation to those countries to arn as Russle had to protect the 11 berty

11. Howard R. Harraro, 3h11le Hazzed, Yireinte's Agent in purope, $p . \frac{35 .}{35}$ 
of the sea. In the Becond part of this lotter he coasented about Ireland and her troubles with England, and of her deslre to be separated from that country.

Two days 1ater on Apri1 21, 1780, Maz2el, st111 writlng frou Parls, explalned to Jefferson that Dr. Benjanin Frank11n had 1nforsed his that he had uneuceosafully tried in Genoa to ralse money for Congress at $s i x$ per cent, and that the opInton of Dr. Franicien was that the Unlted States could not obtaln money in Europe on those terms whlle buropean powers offered. much higher rates. Mazzel, however, had hopes of sueceeding, and he lntended to set out for Italy as soon as his Ilnanees would peralt. He ropeated the necessity of having hlo powers enlarged, and deslred, in case the teras on whlch Congress would choose to obtaln a loan should not be agreeable to V1rglnda, that that state give him leave to act for congress. 12 the conthued that Dr. Irankiln objected to hle miselon very much, saying that "so many people hed come to surope from every state on that kind of buel-

12. Benson J. Lossing, The Amerlean H1 atorl es Record, Vol. 2, 1872, p. 106. 
ness that they had ruined our ored1 t, and made money men shy of us."13

On thay 3, 1780, fros Parls, Mazzel expressed $\mathrm{hlo}$ deslre to persuade Itallans to send to America on their own aceount and at thelr own risk such goods as the Amerleans needed most. Th1s plan had been approved by many in Itely, but Italy could not act openly for soveral reasons. However, only one of these rosaons was given in the letter: "They cannot take the lead of Prussta, Fussta and the Emperour." 14 Mazed outlined a plan by which Itallan adventurers al ght bring thelp goods into America. He had asited Dr. Franklin to Introduce him to minlsters who might be able to help hie work out his plan. Dr. Frankiln at first promised hits these introductlons, but soveral weeks passed, and he falled to show any signs that he vould carry out hls promise to thazed.

On tay 12, 1780, from Parks he wrote to Jefferson glving information coneerning the number of vessels and men in the French rleot whlch had salied for Amertca ten days before

13. Ibld, Vol. 1, p. 33.

14. Wr. Palmer, Calendar of V1rginla state Papors, vol. 1, $1872, \mathrm{p}, \frac{2}{348 .}$ 
uncer Rochambecu. These vessels were carrying ares and clothing to washington's arry. The second divialon of the Fronch fleet was expected to sall early in June, and the Spanish Pleet had salled on April 29, The Engll oh 2leet, for one reason or another, had put back into port for the thrid tme. Hazzel was certaln that the French and Spanish fleets together could conquer the Britlish floet, oven though Ingland had a much stronger pleet than those of spain and France comblned. He polnted out that he saw Ingland's supreasacy of the sea declining and that of France and spaln on the Increase; for France hed no trouble getting young men to en11et, while England had to resort to lapressment. 15

On Way 19,2780 , from Faris Ms, $z$ zel ande the following requeste for information:

It 1s obvlous that the Duropean adventurere cannot, durling the war, fetch from America but a amall proportion of their cap1 tal. my [alo] intentIon has always been to persuade them to leave the greateat part of $1 \mathrm{t}$ in our funds; which would be the means of 1 nteresting them in our welfare, and of

15. Richard Ceoll Garl1 ck, Jr., Hh111e Hazzol, zrlend of Jefrereon: $11 \mathrm{~s}$ Wre and Lotter: p. 64. 
taking a great deal of paper money out of elroulation. the [sie] lato resolutions of Congress, tenalns to so great. and I hope advantageous, alteration $1 n$ our elnances, put to now entirely at a Stand. I am not only unfit to propose any thing, but 11 kewl so unable to give estisfaction to any question on the on the subjeet until you favour we with a clear and thorough Information of the whole, whlch I wish may Soon be the case. … It is highiy necessary that I ahould be scgualnted with 1 t as well as with any new establishment of the kind, If there should be any hereafter In the country.

I shall take 1 t as a partlcular favour if you w11 take the trouble of Inforning we with the new lava relative to Bnlerants, and in short, with evory article of our constitution, and new code of 1aws, apt to satlefy the minds of those who way 6 incline to become our countrymen. 16

The next day llazzel related to Jefforson hls efforts to eorrect the rumor that the Amerloan Colonies might reund te with Ingland. He also sald that he had mace efforts to incuce France to send Amerl ca efrectual. ass stance agalnst thelr common enemy - Wazzel onclosed his plan to defoat the Brith th in Amerlea, a plan whloh was later used to defeat cormwallis at Yorixtown. 27

16. Howard R. Marraro, Th111p Uazzel, Vlrginie's

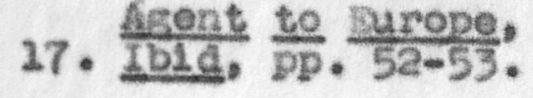


Hazzel sent Jefferson on June 15.1780 ,

a dipping from the Lexcen gazotte.

because 1t contalns several interesting accounte relative to varlous insolvent and Ignominious actions of the BrLtish subjects at sea, and tho disopostion of the marltime powers to prevent guch an BV11, which they are cetormined to dg
by an effectual and lasting remedy.

He ronariced of the Klng of Naples" plane for bullatng up hls navy and of $\mathrm{hls}$ having the atd and guldance of very capable men.

Mazze1 wrote Jerferson agaln on June 22, 1780, and on June 26, 1780. He exprossed the disappolntment he had felt after roading In a Loncon paper of the lose of Charleston. He contlnued that all Amerteans in Europe relt sad about this 10se. On June 26 he resumed this letter by writing.

1 could not find sh this letter before, having been ever alnce I wrote the above, almost constantly employed in publte and pmvate oompanies to ease the minde of our rriende about the 2oss of Charleston. that [ele] unlueky event has brought me to the certaln knowledge, that the number of our hearty friende id infindte, and $I$ have beon exceodingly afrected by thelr foelinge for our just and glorlous cauas.

18. IbLd, P. 56 . 
I have been considered as an angel deseended fron heaven asuons then for havIng assured them that such a loss would not matorialiy affect our operations, and that it $1 \mathrm{~s}$ trifling in comparison to the unshaken Constancy of the Americans. 19

He added that Mr. Mdans had been work-

Ing as he had in Europe to restore fad th in the

United states. He also related that ir. Adans

was much more eaper to help him than was Dr.

FrankILn, who st111 Insl sted that the state of Virginda had no right to borrow money individual1y. Mazze1 des1red to work w1 th Mr. Adans, but wanted Jefforson's approval of this arrangement.

After an elapee of about alx monthe

Hazzel wrote frow Florence on January 5, 1781:

Belng st111 deprived of the honour of an answer from you, I think it a duty to Inform you of 1. You may probably have sent me before now, el ther new Comiselons and Inetruetions, or the duplicates of my first, and expect that 1 have recelved them. Unt11 I do I shall trouble you overy now and then to realind you, that to my great sorrow I am, and must continue to be a useless servant to the state. 20

19. Ib4a, p. 57.

20. IBIC, D. 59. 
He also asked Jefferson to send $\mathrm{hl}$ commis ano and Instructions to $\&$ Mr. Mark Lynch in Mantes ${ }^{21}$, to Ur. John Adams, or to a Mr. Favi22. He made this request because he believed that $\mathrm{hl} s$ all was belng stolen, and if it were sent alreetly to hlw, he would not reoelve these papers. When froa Florence on Aprl1. 8, 1781 , he acknowledgea the recelpt of Jefferson"s commands and also the following papers:

copy of a letter from the Board of trade [o1e], dated at 11111 amburg, 9 th 13 th, 1779 .

Your private letter dated .1111anaburg, Apr11 4, 1780. Three offlctal ones, dated Rlohmona, one llay 12, and two llay 32, 1780. Copy of my commiasion, datod April 22, 1779, and eert1fled by your dxcelloney at Richmond the 16 th of 4 ay 1780 . copy of my instruetions rolative to 1 t, dated and cert1fled as above. COpy of my CommLealon, datod April 24 th certirled as above. Copy of my instruetions of the same date, certlrsed as above, and derlelent of the Invol ce therein mentlonod. Two bunales of my private papers, as aentioned in the same private letters.23

21. Lynch, Mark, a mombor of a banking flrm in Mantes, who befrlended llazzel upon hls arrtval in surope.

22. Ir. Fav1 was agent for the orand Duke of Tuscany in Parls.

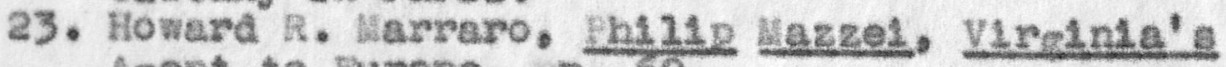
Acent to Burope, p. 60 . 
He related that the above papers axrived In France In July, 1780, but they were never given to him. He added that the board of trade in its letter had forbldden him to purchase the goods for the arvy, on the teriss preseribed in his instructions, without empowering hin to tront on any other. Certain instruations for executing some business 1 intended at $\mathrm{frat}$ to be transacted by a $4 r \cdot \operatorname{sen}^{24}$, as mentioned in one of the governor's Letters, were not in the bundse of papers. Hazel. believed that these lettera had been opened and read before he recelved then. He repeated that w1 thout new powers nothing could be done in regard to the $10 a n .25$

From Plorence on Apri2 26, 1782, Hazzel complained that he had not been offledaliy informed of Benjamin Narrison's election to succeed jefferson as the flrst asgistrate of Virginia. He stated that this lack of Information had humillated him much more than anything else. He observed that the arand Duke of Tuscany and other 1mportant suropean flgures had more than once abked him if

24. Th1s lir. Snith gannot be Identlfled with any degree of certainty. He may have been elthor Captain Granvilie Smith, Mr. Thomas Smith or if. Thuroughgood smith.

25. Benson J. Loss1ng, The Amerlean ML storleal Record, Vol. 1, 1872, pp. 148-149. 
1t were true that Jefferson was no longer covernor. Beosuse he could not anewer, he felt that this "was injurloue to $\mathrm{hla}$ orealt and honor and therefore requested of this country a public declarstion, in order that he might elear his nane from sueptaton." 26

He wrote on JuLy 19, 1782, of his deslre to return to Virginia. Again he mentioned $\mathrm{hls}$ embarrassmeat for want of money curling the time that ho had been on his mission.

On ulareh 8, 1782, he sent from Florence his last recorded offlctel letter. Mazzel sala that 14 had been $\mathbf{1}$ ve months since the surrender of Comwal11s and Jefferson hed not written him durlng this perlod nor had he recelved any flnanelal ald. For these two reasons his stuation in Europe had become very humluating. He 1neluded a short review of all the lettors he had ent to Jefrerson up to that date and commented on the trouble he had with Dr. Frankl1n, who falled to cooperate with him in forwarding his mall. Ho coneluded his lotter by asking Jefferson to forward his commisston without delay so that he could complete his mlesion and return home. 


\section{CHANTER IIX}

1. Thomas Jefferson's Letters to Th1lip Lazzel November, 1785, to August, 1815

Thomas Jefferson wrote many letters to Ph111p Magzel; however, all of then are not avallable. They have elther been destroyed, Lost or have been in the possession of relativee who do not deslre to have then publinhed as yet. Those whl oh I have been able to obtaln are as follows: In November, 2785 , fron Paris Jefrerson anewered MazseL's request about materlal for hls book, Recherches Historlques of Etats Elnie $\mathrm{g}^{\prime}$ Amerlaue, that he was writing on the Un1ted states. He hed alked Jefferson to write him about the Amerioan court syster, and Jefrerson replied, glving his ldeas on the origin and object of the Amerlean courts of chancery, the 11mit of their Jurlscletion and wany other polnts. He wrote:

The purpose for which you requi re this obliges tie to be conolse, as indeed does my situation here, where, as you know, I an w1 thout books which might enable me to enter into detalls, 
I sha1l confine myself therefore to general description only. ... To sketch for forelgners a general 1 des of this court. ${ }^{2}$

About the m1dale of Febmuary, 1787,

Jefferson Inquired of Mazze1 as to the best translation Into Italian of certaln Latin euthors.

On Aprs1 4, 2787, this the from Marse11les, Jefferson wrote another letter in whl oh he told liazel how very ueful his lettere of 1 troduction. had been on his travel through Europe. Jefferson remarked that he had found soveral now seeds and plants which he belleved would grow in Virginia. He also offored hazzel financial assistance ohould he be in need of $10^{2}$ Ageln Jefferson wrote from Lareell1es on liay 6,1737 . In this lotter he desoribed his travele in burope and the vardous routes he had taken. He promlaed to relate in detall to Hazzel all about hi a journey when they met In Farls. He continued by gaylng that he had recelved a letter from the Governor of VIrginla, who had inforaed hia to tell lazzel "that I have romitted hin money ... an aetiling w1 th $k r$. Velb and

1. Paul Lel cester Ford, The Worke of Mhomas Jefferson, vol. 4, p. 473 .

2. A. B. Bergh, The writings of Thomas Jefferson, Vol. 19, pp. $32-33$. 
shall give hin a full account aoon." 3 Jerferwon coneluded his letter by adaing a postscript to a $u r$. Grand to pay mazzel six hundred louls and charge 1 to to Jefferson.

Jefferson inquired of wazzel on Oetober 17. 1787, If coples of portralts of Amerleus Vospuolus, Columb1s, Magellan and cortez could be obtained at reasonable prices. He wanted dazzel to lot him know if wuch coples at111 existed. ${ }^{4}$ Jefferson wrote Mazzel again on Lay 30 , 1795. that he had been busy and for that reason he had been delayed in answering hiv. He added that as soon as he had had time, he tried to arrange with a $3 r$. Blair ${ }^{5}$ to sell wazze1's property. But fir. Blalr had left on a judiclary tour before he could talk to him on the matter. He concluded by telling Hazzel about his frlends in Virginia and what had happened to thes since the last time he had written, whl oh was about 1787.6

On Aprl1 24, 2796, Jerforson wrote the "Fanous Mazze1 Letter" whi oh w112 be d1 scuseed

3. Depertment of state, us.

4. 1510.

5. Tr. Blalr 1s Mazze1's lawyer In Virginia.

6. Departient of State, MS. Host of this letter is very difricuit to road, thus making it ispossible to give fuli detasis of 1 ts contents. 
fully in the section 2 of thls chapter. He ald not write agaln to llazzel unt1 some tive later, the date of his next letter belng July 18,1804 . He excused himself for not having written for some time, and gave for reasone the preseure of orflelal dutles and the 11kellhood of his letters to w1scarry, be opened, and ande an 111 use of. He coneluded that:

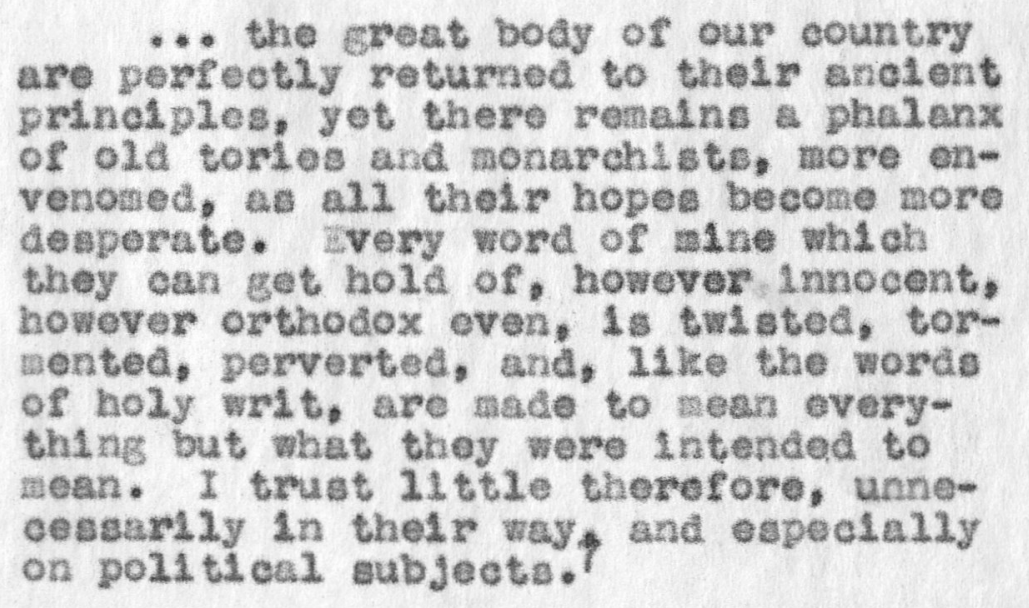
In hls frlendly letter of Warch 17, 1801, written from washiagton, D. C., Jefferson sald that he was sending the letter by a Lr. Short; but slnce he did not know in what way 2t would reach Mazzel, he would not be indsereet about what he wrote. He congratulated Hazel,

7. Ooorge Tucker, The Life of thomas Jefferson, Vol. 2, p. 169. 
who had been marrled for three years. ${ }^{8}$ the explalned:

I perceive by these inquiries in your letter as well as by your express sention, that sy latter letters have not reached you. I have regulariy wr1 tten you once a year.?

other watters that he discussed in hls letter pertained to rinances, business, and friends of Mazzel who wore fll1ing laportant offlees in Washington. He closed by stating that he would not alga his name to the letter because "... of the perils by land and sea to which this may be exposad, but you can be at no loss from whom 1 t comes."10

Fros Monticello, December 29, 1813. Jefforgon narrated the orlgin and progress of the war with Groet Britoin. In the same letter he informed Mazzel that from the sale of hls house and lot in R1 chmond he had oleared $\$ 6342.21$. He concluded that he $w 1$ shed to lnvest the money

8. Mazze1's f1rst wife had dled January $10,2788$. He was married agein, this time to a young woman. He never mentions $\mathrm{hls}$ second wife in his lettors, and it was ondy by accldent that Jefferson learned three years later of the marrlage. In his w112 he calls her "Antonla Mazze1". She bore hia his only chila, a deughter.

9. Paul Lelcester Ford, ed., The Worike of Thones Jefferson, Vol. 9, p. 211.

10. IBIa, D. 212 . 
In VIrglnda since the war with Bngland had rade 1t unate to send it across the ocean. On Naroh 6,1815 , he again wrote Maz201 from Hont1 cel10 that Dr. Barton ${ }^{21}$ was coming to surope for a vialt and curlng his trevel would stop at Florence and Pards. Fhorofore, Jefferson Inforned tazzel that he was sending this letter by Dr. Barton in order to Lntroduce lazzel to $\mathrm{h} 1 \mathrm{~m}$. He promlsed hazzel that Dr. Barton would tell him a.12 about the late war with England and the present state of things in Amertea. Jefferson wrote his last known letter to sazzel on August 9, 1815, expleintng in 1 , as he had in a provious one, the cordition in whl oh Amert ca found herself aftor the war. In addition he asked lazzel for permiselon to use hle money for personal matters, promlatis to roImburge him within a reasonable time; previously Jefrerpon had planned to 1 nvest the money in government bonde and in private enterprise. He al ao deseribed to lazzel the deplorable conattion in which the banka of America found theriselves arter the war because of the deflated currenoy .

11. Dr. Benjanin S. Barton was a good friend of Thomas Jefferson. 
2. The Femous Wazze1. Letter, Apr1. 24, 1796

The "Panous Hazzel Letter" was orlg1na11y wrtten by Thomas Jefrerson only as Informatlon conoerning business, in whloh was Inserted a single paragraph of polltical inforation as to the state of the country. The parggraph used was as follows:

The aspect of our pollt1es has wonderruliy changed elnoe you left us. In plaes of that noble love of 11 berty and ropubli ean govornosent whl ch carried us triumphant1y through the war, an Ang21can monarchical and aristoorat1eal party has sprung up, whose avowed objeot is to draw over us the substance, as thoy have already done the forms, of the Britush government. The main body of our c1tizene, however, rewein true to thel republicen princlples: the whole lended interest is republi aan, and so 1 is a great masa of taients. Agalnst us are the Executive, the Judldary, two out of three branches of the Leglelature, all the offlcere of the coverntent, all who want to be offloers, all timld men who profer the oalm of ceppot1sm to the bolsterous sea of 11 berty, Br1t1 oh merchants and Amerlcens tradIng on British cap1tals, speculators and holders in the banks of publle funds, a contrivanee invented for the purposes of corruption, and for aselmilating us In al1 things to the rotten as well as the sound parte of the Brit1sh model. It would give you a fever were I to naine to you the apostates who have gone over to these heresled, men who were Samsone in the fleld and Solosons in 
the counc11, but who have had the1r heads chorn by the harlot. In ahort, we are 11kely to preaerve the 11 berty wo have obtalned only by unroal tting labore and. per12s. But we sha12 preserve $1 \mathrm{t}$, and our mess of welght and wealth on the good alde is so great as to leave no danger that force 111 ever be attompted agalnst us. We have only to awake and snap the Li211putian cords with whloh they have been entangling us durlng the flrpt sleep whi oh acceeded our Labors. 1

Mazzel, ever eager to make publle in Italy nowa frow Amerloa, translated the pollt1as part of this letter without authority and had $1 t$ published in an Italian nowspapor. Th1s step, however, was only the beginning. On January 25, 1797, the "Hazze1 Letter" appeared again, only this time $1 t$ was another translation in the French nowgpaper yoniteur. On Hay 14, 1797, an Atwerloan newepaper, the Mlrerva, carried an lang11.h translation of the French veralon. The extonsive publication of this letter caused a great controversy in Amerlea and surope.

The Foderallste, after reading the lng11 bh translation, used it as a politloal weapon agalnst Jefferson, who was at this time vice-

1. Henry S. Randa11, The Hife of Thonas Jefferson, Vol. 2, pp. 295-296. 
president of the united states. They malntalned that it had been alwed as rectiy at their party and thelr leader, George wabhington. Jerferson at flrst did nothing to olear himself, fearing thet an explanation would be misconstrued and only make atters worse. However, all this oritiel sm and trouble did not prevont Jerferson's belng elected fresident in 2800.

A story was elreulated stating that washington had eeverely alled Jefferson to account, and that Jefferson had apologlzed and explalned. Jefforson denled that there had over passed a word, elther written or verbal, directIy or Indireotiy, between washington and hissels on the matter. ${ }^{2}$ on the whole, therefore, he thought 1 best to resaln silent; but because he was anxious to coneult with his friends, he sent James Iradison an Invitation to come with James Honroe to "Monticel10" for the purpose of discusalng what he should do. A resume of the letter that Jefferson wrote to Madson 1 as followa:

2. John T. Morse, Jx.. Thomes Jefferson, p. 164 . 
He stated that he could not avow the letter as it stood, for there were oome material alteratlons in $1 \mathrm{t}$, partioulariy that of the forme of the Brit1 sh governient, Insteed of fom; nor could he correct this error without involving himsolf in a personal alfference w1th overy meaber of the executive, the judidary, and with coneral Washington! : that thorefore, he suggests, allence would be his best course. It would embroll him also with all those with whom his charactor is t111 popular, that is to say, nine-tenthe of the people of the Uns ted States.?

There was no coollng of frlendahlps between Jefrereon and Mazzed because of this letter, but frow this thme on Jefferson was very careful not to algn the next letter ho wrote to Mazzel. 4

Mazzel should never have translated and published the letter w1thout authority. Howover, he eannot be held reaponsible for any slgnifleant inaccuraey of translation. The only change he made was to translate "In short, we are 11 kely to preserve the 11 berty we have obtalned only by unremltting labors and perils. But we shall preserve then..." Into "Insomal conserveremo probablimente 1a 11 berta che abblamo

3. coorge Tucker, Life of Thomas Jofforson. Yol. 2, D. 25.

4. Rlohard Cec11 Gar11 ok, Jr.. Mh111p Mazzel, 2riend of Jefrerson: H4s L17e end Lettere, p. 137. 
aequistata, col sole mezzo $a^{\prime}$ incessanti fatiche - perleoll, wa 1a conserveremo...", the alteration belng from "we shall proserve then, to "we shal1 preserve 1t".5 There was another 1mportant change to which Jefforson objected. It occurred in transposing the word "forms"Into "form". Howover, it has been polnted out by historlans that Maszel elearly had 20 formallta. 6 Jofforson also complained that the wording of the letter had been changed quite a blt. Wany hlstorlans have declded that the oholce of words was IIIproved by Hazze1. It $1 \mathrm{~s}$ renarkable that the letter could have beon translated so many times and st112 be so much $12 k$ ke the origlnal. The rest of this nanuscript is of 11 ttle Importance. It deals with Plnanclal asters which Jefferson was banding for lasze1. He tells Mazzel about some good squash soeds he is sending, asking Ileszel to put a fow seods in overy letter he writes Jefferson.

5. IBS, 137.

6. Finry s. Randal1, The liffe of Thomes Jefferson, Vol. 2, p. 261. 
CHAPTER IV

2. Mazze1's Letqero to Jerferaon

The following letters conprise the

Irlendly correspondence of FhI1p lazzel to Thoaas Jeffereon over a pertod of yeare unt12 the former's desth on Wareh 19, 1816.

The flrat of these frienaly letters, as far es 18 known, was that in whl oh Nazzel wrote on Apr11 4, 1784, to Jerfereon of his arrival on November 19 at Hampton and of his journey to Rosewell where he desired to rest for a week or two. He added that as soon as elrcunstances peraltted, he would visit his. He also Infomed Jeffergon that he was vistung in the home of Hadson's father and that liadson had. told him of the economie and polltical affalrs of the confederation. He promised that he would have much to say in reference to the "necesalty and tanner in which to set forth and stabsilze on good and colla foundations our commerce on this alde of albraltar, where all the states from Wew Hampahl ro to deorgla could 1 ind groat advan- 
tage in the rest of Durope." 1 He told Jefferson that he had a great aeal of material on this oubJeet and that instead of writung it in this letter he would ssve $1 t$ unt1l, he vialted Jefferson at a later date.

Mazzel stated that he was Alspleased to hear that certain occupatlons in Amerloa would be elosed to the forelgn born. He also regretted that in some countries of surope only those who were natives were elogible for certain posituons. The most laportant part of this letter was the conclubion in which he alscussed his commlseton:

Since all the relative records of ay publle comisalon are 10 st, as well as iny letters written froti Durope to the goverment, I an obliged to recall. from momory those whi eh I shall need and from thelp bucoessors all that whl oh 1o to satisfy the present menory ouggestg. I shall be very grateful to you. ${ }^{2}$

On Hay 20,2784 , Masel sentloned hla vidt w1th Patriek Honry. He also Informed Jerferson that he learned that Van-stophorst (reforred. to In Mazzol's Lottors to Jerferson as V. S.) was leaving for Durope. Mazzel wrote that thle news was a surprising blow because ho had hoped to re-

2. Department of State. Ws. 
celve advice from Van-stophorst in the difralt altuation in whloh he found himself involved. For a dobt of a hundrea 21 res a col. Whiting had had hin $1210 g a 11 y$ arrested because Wazzel already had pald the debt, and he had a reoord of 1 in his books and papers wh1 wh were at Mont1ee110. He asked Jefrerson for acvice on thas matter and the neans of obtalndng hls books and papers. Mazze1 remeriked on Decenber 1,2784 , that he shoula be on $\mathrm{hla}$ way to Burope, but that ho had been detalned for vartous reasone. Sieveral lettera of Importance had been given him to dellver to "V. S." on his arrlval In Durope, but beause of his unforkeen delays in departure he malled them to Jerferson who was at this the porelgn ulnister to France, asking hita to deliver thes for him. He promised that he would wrtte more at a later date, when he would have more twe.

On July 9, 1785, Lazze1 Infomed Jefferson that he left New York on June 17 and had Just arrived in burope. Ho continued that he had with him "wany bundies of jetters and other papera for V. S. I cannot be In Parls before 
the 21 or 22 of this month; ... I deen 1t proper to bring all the papers ayself not lenowing that which cenands the most urgent attention." 3 He elosed by sayling that he was having troublo with his weht hand and therofore could not write too wuch because of the pain. He postponed telling his frlend about America until he vist ted Jefferson later on In Parla.

On Oetober 26, 1785 , Mazzel wrote our yndeter to pranee that he was sorry he must leave for HoLland wl thout flrst having tine to seo jefferson. He told him of $\mathrm{hls}$ visl ts to a frlend, a certaln lir. W1111ans, whom he was helpIng financially by glving bim a few erowne each day or so. He asked Jefferson to write Mr. W11llams and ocesalonally to send him some money. The following yoar on robruary 6,1786 , Mazzel wrote a long frlenaly letter to Jefferson about various things. He sald that a Mr. Luzas was 1nterostod In Mazze1's "Plmsstranze.

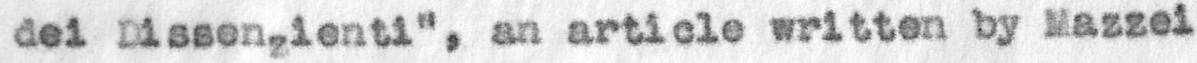
cosorlbing the atate of affalre in Amertca at that part1oular time. He also astred Jeffermon 
to send 5 . Luzas aome congresstonal materlal on the div1asng of Virginis into two states. Luzss wanted this information so that ho could publiah 1 t in order to contredl ot wrlters who were 1 nslnuating that relatlonghlp between the states was in groat confugion. He requested that Jeffergon write Wr. Luzsis a paragraph demonetratsing that "the diviesono of VIrginda Into two states never eneountered opposttion In the mind of a senotbie person. a $^{4}$ liased aleo desired that jefferen sond his an account of the boglnning, progress, and rall of c1nolmat1. on Fobruary 20, 1787, fros Parte; tistze1 sent Jefferson a very short note $1 \mathrm{n}$ whis dh he told hin that he hed recelvod twenty-11ve louls of gold from Jeffereor, and ho proms sod to pay bsok stx hunarea pound sterling at a later aute. 5

Hazze1, on Apr11 17, 1797, thanked Jofferson for his generous offer of alding hla flnanclally. "If you w12 send we a gmall anount, I ahall use 1t in case of an evergency, or I

4. R1chard geoll Garlick, Ir. Zh114p Mazzel; Exlend of Thomas Jefferson: His Life and Letters, p. 102.

5. Dopartment of State. ME. 
ahal1 return 26 to you when you retum." 6 He also informed Jeffereon about tholr varlous rriende, one in particular, Marchose?, who was 111. and liazel begged Jefrergon to drop thel $r$ alek frlend a 11 ne to cheer hin up. He concluded that he had already started having his works 8

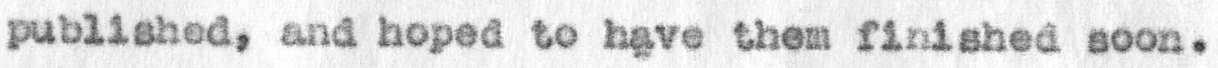
On July 4, 2709, Hazzel wrote to Jorferson that he hed heard frow rextable sources that the latter was golng to v1ast $1 \mathrm{n}$ Amerlea and that he was dellghted to leam the good nowt. He pral sed Jeffereon for his Kunaness and the good work he had done for the Amerloan people. 9

As oltizons of the United states we feel a laudable pride 1 n jolning the general volco of our country and of that of the age in which we live in rendering the alnoorest tribute of reapoot to an compstriot so distraluhed for his exertlons in your partloular kinaness and attention to every Atwerlcan who has salled in your way have endoared you to thelr hearts; and wo

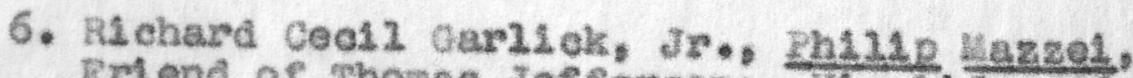
Fuend of Thomas Jefferson: $11 \mathrm{~s}$ LIe and Letters, p. 109.

7. FrobabIy La Fayette.

8. The book llazzel $1 \mathrm{a}$ writhng on the und ted states.

9. Thomas Jefferaon was at this thine Amertes's Forelgn Mindster to Franee. 
are sure, as we speak the language which thoy have often uttered on this subjeot, that wero they ail present they woula Joln $\ln$ this our nost coredal scimpwleagrent. $10^{\circ}$

Th1 Letter was algned not oniy by Mazzel, but by a number of men, sone of whon were John Paraas se, Samuel Blackdon, Tod Barlow, Z. Haskel1 and Th. Appleton.

Jefferson had sent Mazzel a letter in whl ah he told of the death of tazze1's friend, Bellint. ${ }^{11}$ Then, on Septeaber 12, 1802, Lazsel answered Jefferson, expresulng brlefly his sorrow at the death of his frienc.

He also wished to have printed a volune of Jefferson's works, Ineluding hls Inaugural addresses and other excerpts from hls writings. He wrote that he had found the two Bculptors about whow Jefforson had Inquired in provious corresponcence. At the close of the letter appeared the recurring thene: "I shall speak of money transactione between this and

10. Departaent of state, wis.

11. $\operatorname{car} 10$ Be112nis, $(1735-1804)$ was a 72 orentine. In 2779 he became a profeswor at the college of Fill am and Hary, teachlng Frenoh, I tellan, Span1sh, and Jeman. He canse to Amerlea to ald hazzel in his agricultural work. 
that country. I ask you to pay ciose attention bocause 1 thay becowe an Important aubject." 12 Fros P1as on September 18, 1814, Maz2el. wrote his last letter to his doar rmend. For the second tise he requested Jefferaon's inaugural apeech to congreas. He explalned that now ho was an old man, elchty-four yoars of age, and, unless the apoech came goon, ho might not be able to read 1 t.

He thanked Jefferson for having sold his house and lot in RL chmond and romerised that he had recelved more for 1 t than he expected. Then in the conclusion of this last letter to Jefferson, Mazzel bewalled, as he had done repeatedy, his 1mpecunious conditions

You probably lanow that the tryanny of llapoleon has rulned all. the towns that he has entered, and that the 1nd1v1duals most harmed and tzmenied were the known or supposed enemles of the regine. Conseguently I have been one of those nost persecuted: thus my Inances have suffered much, and I would be much relleved if I could witharaw iamediatelg the funds from the land in Rl chmona.

12. Meharâ ceell aarlick, Jr., Ph11.2p Mezzel Friend of Thomse Jefferson: $11 \mathrm{~g}$ Lre and Lettere, 1.249.

13. 1610. 160. 


\section{2. conclusion}

PhL11p Wazze1" g greateat contribution was his struggle for the independence of the young stated of America. How he came to these states at the suggestion of Donjanin Franklin and Thonss Jeffereon to Lnethtute on aprd cultural experisent and how he later wes aent to Europe as Virglnie'a agent are well known fects. However, the grest Influence be exerted on coIonlal readers is hardly appreclated. He worked to bulld an Amerlcan republse ard to change the attitude of the Amerlean people and thelr Ieaders towarde British pol1tical ineti tutions. He was well acqualnted with then, for he had 11ved el ghteen years in inglend. The method he used to influence the people was a denunciation of the Br1t1sh Government and the olssesinat1on of the principles of equality and true demoaratie government by means of the writing of numerous art1eles whloh were publ1shed about 1774 to 1775 In a Virginia nowspaper. Hiatorians have found. from research that sose of the very expreastons used by thoman Jefferson are exsetiy like some 
of those which appeared in thazel's art 1 cles. Hezed's wseton 1 surope as agent for virginia was coneldered a fallure. He spent three years in Burope as VIrglnia's agent wLthout recelving runds and wLthout seans of securing any. However, this ald not prohiblt tazzel from trylng to serve his adopted eountry with zeal and tact. He sent home to Jefrerson wheh Inforastion that undoubtediy proved Invaluable to the nev republle. There 1. no doubt that he helped strengthen Amemea's posttion abrosd and eorrect many rumore which ml ght have proved injurlous to Amertan credt In Trance. $\mathrm{Ha}_{\mathrm{g}} 201$, it must bo remenbered, alded In securdng mi.11 tary and rinanolal asel stance from the french governtsent, and also oredit is cue hin for the eapture of corawel11s at Yorktown.

Yet, after all thls hse been sald, one can subsorlbe to the worde of Arthur ligh olough ${ }^{2}$ when judelng this energet10 Italian 1 mat grant: "How pleasant $1 t$ is to heve money b"

2. 2819-1862, Bpectator ab Extra. 


\section{BLb210graphy}

\section{Primery sources}

1. Bergh, Albert Ellery: The Eritings of Thonse Jefferson, Moworiel zaltion, wahlngton, D. O., 1907, 20 Vole.

2. Department of State Henuscripte, Washington, D. C. 3. Ford, Paul Lelcestor: The Norkg of Thonas Jefferson, New York, a. P. Putnam' a Sons, 1894, 12 vols.

4. Hanilton, J. H. De Roulhoe, the Best Letters of Thosas Jefferson, Boston, New York, Houghton, M1frun and company, 1926.

5. Jeffersontan Cyclopedta (LAl ted by J. P. Foley),

New Yoris and London, Funk and vagnalls, 1900.

6. Jerferson's Notes on the state of Virgtnia,

Baltimore, wechln, 1800,

7. Marraro, Howard R., DhL112 HazzeL. YMrgLnIa's Arent in Durope, Nev Yorls Publie Library, 1935. 
8. Palner, wilisan P., Galendar of Vurcinia State Papers and othor Hanuseripts, RA ahaond, VIrginia, R. F. Veliker, supt, of Fublie Printing, 1875.

9. Washington, Henry Augustine, the Neltinge of Thonan Jefferson, washington, D. O., Tay1or and Maury, 1853-1854, 8 Vols. 10. W114an and Wary collere quartorly, rirst and second semes, w1111angburs, V1rginia, 1891-1936, pr. E. C. aranohl, Tr.. "Menol re of PhIMp Hazze1". 
B1b11 ography

Secondery sourees

1. Atlantie Nonthiy, Boston, James $\mathrm{k}$. Osgood and Company, 1872, Vo1. 30, James rarton, "Jefferson covemor of Virginia".

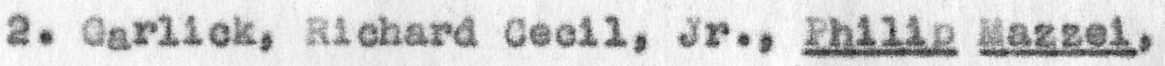
Exiend of Jefrerson: His Hre and Letters, Daltimore, the Johns Hopkans jreas, 1933.

3. Hirst. F. W. L4fe and Letters of Thonas Jefferson, New York, Haca1.11an Compeny, 1926.

4. Lossing, Benson J.s The Aneriean Hiatorleal Becord. and Renertory of Noter and guerios, Fh12sdeIphia, chase and Town, Fublishers, 2872.

5. Woree, John $F$, Mhomas Jerfergon, Bogton and Now York, Houghton, Mifrun and conpany, (e. 1898).

6. Randal2, Henry s., The Lhre of thomse Jefferson. New York, Derby and Jacksor, 1858, 3 Vola.

7. Randolph, Sarah N.. Doment1e Lfe of Thomas Jefferson, New York, Harper and Brothers, Publ1 aher, 1872. 
8. Tandolph, Thomas Jefferron, Lemolr, corregDondence and Meedlantes from the Papers of Thoses Jefferson, Charlottesv111e, Virginia, 7 . Carr and Conpany. 1829, 4 Vols.

9. Samuol, Frank1in 3., The Complete Anse of thosuse Jefferson, New York, The Round Table Prees, 2903.

10. Sohlano, Jiovanni, The Itallang in Anerieg Before the elvil anx, Now York, the Vargo Fress, 1934.

11. Tucker, doorge, Life of thomas Jeffereon, rhlladelphia, Carey, Loa and Blancherd, 1837. 2 Vols.

12. VIrginia's Historicel Index, (EALted E. A. Swen), Roanote, V1rgin1a, the stone Publishing and llanufaoturing Conpany, 1934. 


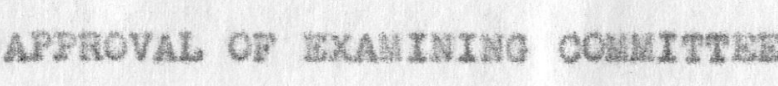

Thoues E Eunis,

wesh

$$
\frac{\text { T. L. Aarria }}{\text { c. Alambe }}
$$

